\title{
1 The dynamics of natural pipe hydrological behaviour in blanket peat
}

2

3 Smart, R.P. ${ }^{1}$, Holden, J. ${ }^{*}$, Dinsmore, K.J. ${ }^{2}$, Baird A.J. ${ }^{1}$, Billett M.F. ${ }^{2}$, Chapman, P.J. ${ }^{1}$ and Grayson, $4 \quad \mathrm{R}^{1}$

$5 \quad{ }^{1}$ School of Geography, University of Leeds, Leeds, LS2 9JT, UK

$6 \quad{ }^{2}$ Centre for Ecology and Hydrology Edinburgh, Bush Estate, Penicuik, Midlothian, EH26 0QB, UK. 7

8 *Corresponding author: j.holden@leeds.ac.uk; tel: 441133433317

9

10 Date submitted to Hydrological Processes: 17 May 2011 


\section{Abstract}

13 Natural soil pipes are found in peatlands but little is known about their hydrological role. This paper

14 presents the most complete set of pipe discharge data to date from a deep blanket peatland in northern England. In a 17.4-ha catchment, there were 24 perennially-flowing and 60 ephemerallyflowing pipe outlets. Eight pipe outlets along with the catchment outlet were continuously gauged over an 18-month period. The pipes in the catchment were estimated to produce around $13.7 \%$ of annual streamflow with individual pipes often producing large peak flows (maximum peak of $3.8 \mathrm{~L}$ $\mathrm{s}^{-1}$ ). Almost all pipes whether ephemeral, perennially-flowing, shallow or deep (outlets $>1 \mathrm{~m}$ below the peat surface), showed increased discharge within a mean of 3 hours since rainfall commencement and were dominated by stormflow, indicating bypassing flow from the peatland surface to the pipes. However, almost all pipes had a longer time period between hydrograph peak and return to baseflow than the stream (mean of 23.9 hours for pipes, 19.7 hours for stream); as a result, the proportion of streamflow produced by the pipes at any given time increased at low flows and formed the most important component of stream discharge for the lowest $10 \%$ of flows. Thus, a small number of perennially-flowing pipes became more important to the stream system under low flow conditions and probably received water via matrix flow during periods between storms. Given the importance of pipes to streamflow in blanket peatlands, further research is required into their wider role in influencing stream-water chemistry, water temperature and fluvial carbon fluxes, as well as their role in altering local hydrochemical cycling within the peat mass itself. Enhanced

31 piping within peatlands caused by environmental change may lead to changes in streamflow regime with larger low flows and more prolonged drainage of the peat.

\section{Introduction}


Natural soil pipes are large macropores that act as conduits for water, solutes, dissolved gases and sediment. Natural piping, which often produces macropores many centimetres in diameter, is sometimes referred to as 'tunnel erosion' (Crouch et al., 1986; Zhu, 1997; Zhu, 2003), although the exact process of pipe formation may include faunal tunnelling (Holden and Gell, 2009), root penetration, which opens up a macropore, and crack formation during desiccation (Bryan and Jones, 1997). Subsequent enlargement may take place through a combination of physical erosion of particulates or solutional denudation. The pipes or 'tunnels' can often be several hundred meters in length and typically form branching networks. Natural soil pipes have been reported in a range of environments such as tropical forest soils (Baillie, 1975; Chappell and Sherlock, 2005; Sayer et al., erosion has often resulted from pipe development (Bryan and Jones, 1997; Crouch et al., 1986; Gutierrez et al., 1997). cause peatlands to be susceptible to piping (Holden and Burt, 2003a; Rosa and Larocque, 2008). 1987), subarctic slopes (Carey and Woo, 2000), steep, temperate, humid hillslopes (Terajima et al., 2000; Uchida et al., 1999; Uchida et al., 2005), and dispersive semi-arid soils, where severe gully Macropores have been found to be important for infiltration and throughflow in peatlands (Baird, 1997; Holden, 2009). Larger pipes have also been commonly reported in peatlands (e.g. Glaser, 1998; Gunn, 2000; Holden, 2005a; Holden and Burt, 2002; Holden et al., 2004; Jones, 1981; Jones et al., 1997; Markov and Khoroshev, 1988; Norrstrom and Jacks, 1996; Price, 1992; Rapson et al., 2006; Thorp and Glanville, 2003; Woo and DiCenzo, 1988). Soil conditions are generally too harsh for burrowing fauna in most peatlands, but peatlands may be conducive to piping because they are susceptible to rapid desiccation cracking. Outside of drought periods, the plentiful supply of water combined with a highly variable range in hydraulic conductivity within the peat profile may also cause peatlands to be susceptible to piping (Holden and Burt, 2003a; Rosa and Larocque, 2008). 
Natural pipes in peatlands have been most frequently reported in blanket peatlands (Holden, 2005a; Jones, 1981; Jones et al., 1997; McCaig, 1983; Price, 1992). Pipes may be important in the delivery of water to blanket peatland streams. Jones and Crane (1984) reported that $49 \%$ of streamflow was produced by soil pipes in histic podzols in mid-Wales. It was suggested that the pipes transmit water to the stream from an area on the hillslope 10 to 20 times greater than would be the case if all stormwater were drained via surface and near surface flow (Jones, 1997). This shows the potential of pipes to deliver water, solutes, dissolved gases and sediment directly to the stream network from more remote areas of the peatland, which would be considered disconnected under the traditional view of peatland hydrology. There has only been one detailed study of pipeflow in a deep peat catchment where it was suggested that $10 \%$ of streamflow moved through the pipe network (Holden and Burt, 2002); this study was over a limited (five-month) period so it is not known whether the results are atypical. We still know relatively little about the hydrological role and behaviour of pipes in peatlands. While some pipes form at the interface of soil horizons (Jones, 1994; Jones and Crane, 1984), other pipe networks may occur at a variety of depths within the soil profile (Holden and Burt, 2002; Holden et al., 2002) and may, therefore, connect shallow and deep sources of water. In ombrotrophic peatlands, deeper peat layers have traditionally been assumed to be associated with little or no water movement, such that they have a minimal role in supplying streams with water. However, where pipes connect deep peats with streams, the hydrological behaviour of peatlands may be more complex than previously thought (Holden and Burt, 2003b; Morris et al., 2011).

In the study reported here, the overall aim was to investigate whether the contribution of pipe flow from blanket peatland is an important component of streamflow. Our data represent the most extensive continuous record of pipe flows in a deep peat catchment to date. We also investigated how pipe discharge varies spatially and temporally (in response to storm events) in order to 

characterise the hydrological function of the pipe network. The work builds upon a study showing that the pipe outlet morphology at our study site is highly dynamic (Holden et al., in review) and that the pipes act as important point sources for dissolved gases (Dinsmore et al., in review).

\section{Study site}

Cottage Hill Sike $\left(54^{\circ} 41^{\prime} \mathrm{N}, 2^{\circ} 23^{\prime} \mathrm{W}\right)$ is a headwater of the River Tees on the Moor House National Nature Reserve in Cumbria, northern England (Figure 1). The catchment was chosen (i) because of the availability of long-term data on water table, vegetation, meteorological conditions, and soil and stream chemistry which have been collected at the site since 1991 as part of the UK's Environmental Change Network (ECN) (Sykes and Lane, 1996), and (ii) because the site had an existing stream gauging station forming part of the UK's Centre for Ecology and Hydrology's (CEH) carbon catchments programme (Billett et al., 2010). The catchment area is 17.4 ha with an altitudinal range of $545 \mathrm{~m}$ to $580 \mathrm{~m}$ above mean sea level. Lower Carboniferous sequences of interbedded limestone, sandstone and shale provide a base for glacial till at the site (Johnson and Dunham, 1963). The till impedes drainage, which has allowed blanket peat to develop. Ninety-eight percent of the catchment is covered in blanket peat (Adamson et al., 1998; Miller et al., 2001) which is typically 3 to $4 \mathrm{~m}$ thick, although in places it reaches $8 \mathrm{~m}$ thick. Slopes within the catchment vary between 0 and $15^{\circ}$, with the majority of the catchment (>80\%) having slopes between 0 and $5^{\circ}$. Catchment aspect is dominated by east to southeast facing slopes. Vegetation cover is most commonly Calluna vulgaris L. and Eriophorum vaginatum L. with some Empertrum nigrum L. and Sphagnum capillifolium (Ehrh.) Hedw..

The climate at the site is sub-arctic oceanic (Manley, 1936; Manley, 1942). Holden and Rose (2011) produced a corrected and homogenised temperature record for the site for 1931 to 2006 . The mean annual temperature at the site increased from $5.1^{\circ} \mathrm{C}(1961-1990)$ to $5.8^{\circ} \mathrm{C}(1991-2006)$. Mean 

slightly seasonal with $57 \%$ occurring in the winter half-year from October to March. Snow cover is sporadic and a typical winter season will see several complete accumulation and melt cycles. On average there were 41 days per year with snow lying on the catchment between 1994 and 2006 (there were 69 days per year between 1952 and 1980).

The streams across Moor House tend to be 'flashy' with rapid rising and falling limbs on hydrographs. Trout Beck (11.2 $\mathrm{km}^{2}$ catchment), into which Cottage Hill Sike drains, displays mean peak lag times of 2.8 hours between peak rainfall and peak discharge (Evans et al., 1999), and annual runoff coefficients of 70 to $80 \%$. Water tables at the ECN site (Figure 1) are within $5 \mathrm{~cm}$ of the surface for $83 \%$ of the time and rarely fall to depths of greater than $20 \mathrm{~cm}$. Overland flow and shallow throughflow in the upper few centimetres of the peat dominate runoff response and there appears to be little deeper flow through the peat matrix (Holden and Burt, 2003c), with low, but highly variable, hydraulic conductivities measured at depths greater than $5 \mathrm{~cm}$ (Holden and Burt, 2003a). Cottage Hill Sike streamwater has a mean $\mathrm{pH}$ of 4.3 and a mean Ca concentration of $1.1 \mathrm{mg}$ $\mathrm{L}^{-1}$ (1993-2007) indicating little base-rich groundwater influence. The stream is rich in dissolved organic carbon (mean concentration $18.8 \mathrm{mg} \mathrm{L}^{-1}$ ) with an average $(1993$ - 2007) annual flux of 23.4

$129 \mathrm{~g} \mathrm{C} \mathrm{m}^{-2} \mathrm{y}^{-1}$ (Billett et al., 2010; Tipping et al., 2010) with highest fluxes occurring during the 130 wettest years (Clark et al., 2007).

\section{Methods}

133 Pipe outlets were mapped throughout the whole catchment and were visible along the banks of the

134 main stream channel and tributaries and along depressions in the peat surface. A total of 84 separate 135 pipe outlets were identified. All pipe outlet positions were mapped using a differential global 136 positioning system (dGPS) and visited under varying weather conditions to identify their individual 
flow regime. From these surveys 24 pipes were identified as perennial (continuously-flowing) and

13860 as ephemeral (flow ceased under dry conditions). The distinction between perennial and

139 ephemeral pipes is partly qualitative because during the driest conditions flow from many perennial 140 pipes was barely detectable. Approximately $10 \%$ of the pipes (eight) were chosen to provide a 141 representative sample of the pipes within the catchment as a whole (based on size of outlet, depth 142 and whether ephemeral or perennial) for continuous gauging (Table 1). These pipes are described 143 herein using a numerical coding P1-P8 (Figure 1). Based on initial observation, if pipe flows from 144 an outlet were expected to be large then v-notch weirs were fitted at the outlets; if they were small 145 then tipping bucket flow gauges were attached to the pipe outlet. For the v-notch weirs, Trafag 146 DL/N-type pressure transmitters with data loggers were installed within stilling wells. Stage was 147 recorded at 15-minute intervals and represented an average of one-minute stage readings. Stage was 148 converted to discharge using a manually-calibrated rating curve for each weir. Pipes with lower 149 maximum discharges were fitted with Davis Rain Collector II tipping bucket rain gauges, with pipe 150 water conducted to the bucket via plastic guttering. Tipping buckets were automatically logged 151 using Novus LogBox DA dual input data loggers. Stream discharge at the Cottage Hill Sike 152 catchment outlet was measured using a glass fibre flume with recording initiated in December 2007. 153 Stage in the flume was measured using a non-vented In Situ Inc. Level TROLL 300 pressure 154 transducer with atmospheric correction provided from an In-Situ Inc. BaroTroll sensor. Water 155 depth in the flume was converted to flow by a rating equation manually calibrated via dilution 156 gauging. For very high flows this rating was further checked against a calibration with Trout Beck 157 which is gauged only $400 \mathrm{~m}$ downstream from our site. Precipitation within the catchment was 158 recorded using a tipping bucket gauge which recorded the timing of each tip containing $0.2 \mathrm{~mm}$ of 159 rainfall. All pipeflow loggers were downloaded every two weeks between 24 April 2008 and 11 160 November 2009. To avoid seasonal bias we report results for the 12 months from 24 April 2008 161 unless otherwise stated. Since the logger for P1 malfunctioned for $46 \%$ of the time we only used 
the data from it for individual storm analysis; there were insufficient data to produce a complete annual flow budget for the pipe.

165 Storm response variables including total storm discharge, start lag time (time from rainfall start to 166 initial rise in flow), peak lag time (time from rainfall peak to flow peak), time to maximum flow 167 (time from initial rise in flow to peak flow), peak flow, 6-hour recession rate (flow $6 \mathrm{hr}$ after peak 168 flow divided by peak flow), recession time (time from peak flow to pre-event discharge), and hydrograph intensity (peak flow divided by total storm discharge) were derived for each single peaked storm unaffected by snow melt in order to try to characterise pipeflow response. These were measured for each pipe and the stream outlet for as many individual storms as possible during the 12 months from 24 April 2008.

Because pipes do not have clear topographic catchment areas, Jones (1997) advocated deriving a surrogate basin area or 'dynamic contributing area' (DCA) for pipes using storm discharge and rainfall information. This was done by dividing the total storm discharge from each pipe by the total storm rainfall and assuming a storm runoff coefficient of 1 to derive the maximum DCA. The maximum DCA calculated for each pipe during the study was then determined. For some pipes we analysed over 100 storms and so the largest DCA is unlikely to be greatly underestimated.

181 Water table data were provided by the ECN derived from a 5-cm diameter dipwell (Figure 1) fitted 182 with a pressure sensor that measures levels every five seconds which are then averaged and 183 recorded hourly. These readings were checked manually once every week. Holden (2000) reported 184 a mean absolute difference between manual and logger readings of $1.1 \mathrm{~cm}$ at the site. 
Because we continuously gauged only eight of the 84 pipe outlets within the catchment it was necessary to upscale the results to produce an estimate of total pipeflow. This was calculated based on 24 perennial and 60 ephemeral pipes. The annual average flow from the gauged perennial pipes was multiplied by the total number of perennial pipes within the catchment to give an estimate of perennial pipe flow. The same procedure was applied to the ephemeral pipes. All estimated pipe flows were then summed to provide an estimate of the proportion of discharge from the catchment attributable to pipe flow.

\section{Results}

Precipitation for the 12 months from 24 April 2008, was $2105 \mathrm{~mm}$. Total discharge at the catchment outlet was recorded as $305212 \mathrm{~m}^{3}$ giving a runoff to rainfall coefficient of $83.5 \%$. Over the two year period from 1 Jan 2008 the runoff to rainfall ratio was $81.0 \%$. The maximum rainfall intensity during the entire 18-month pipeflow study period was $18 \mathrm{~mm} \mathrm{~h}^{-1}$ measured on 1 July 2009. Maximum daily rainfall (i.e. not affected by snowmelt in the gauge) was $73 \mathrm{~mm}$ recorded on 17 July 2009. Peak discharge was $1375 \mathrm{~L} \mathrm{~s}^{-1}$ on 15 February 2009 associated with a snowmelt event.

Maximum pipe discharges measured across all pipes during the study were found at P3 and P8 where flows of 3.9 $\mathrm{L} \mathrm{s}^{-1}$ (11 November 2008, P3) and 2.7 L s${ }^{-1}$ (3 December 2008, P8) were recorded, both probably associated with snowmelt events as air temperatures were just above freezing at the time. Deep and shallow pipes and ephemeral and perennial pipes all produced large discharges during storms (Table 1); the maximum total storm discharge delivered by P3 was 183 $\mathrm{m}^{3}$, equivalent to $3.8 \%$ of the stream's total storm discharge at the catchment outlet. There was little variability in estimated total annual runoff to rainfall ratio between pipes (23 to $29 \%$ ) based on the estimated maximum DCA. 
211 Representative pipe and stream hydrographs (Figures 2 and 3) show that all gauged pipes responded 212 rapidly to rainfall, producing steep rising and falling limbs. Two of the pipes (P2 and P7) had very 213 steep falling limbs and responded very quickly to all rainfall events in comparison to other pipes.

214 Flow from P8 switched on and off very quickly and thus had the most flashy hydrographs as 215 measured by the hydrograph intensity index (Table 2). However, five pipes (P4 to P8) had a smaller 216 mean storm hydrograph intensity index than the stream. Flow was initiated in all of the monitored 217 pipes within three hours of rainfall commencing, except at P8 which had a mean start lag time 218 longer than that of the stream (means of 4.4 and 3.5 hours respectively; Table 2). There was a wide 219 range in peak lag times (time between peak rainfall and peak discharge), with P2, P4, P6, P7 and P8 220 having shorter mean peak lag times than the stream and the other three pipes having longer mean 221 peak lag times than the stream (4.5 hr). All of the pipes (with the exception of P8) had longer mean 222 recession limbs than the stream $\left(\mathrm{T}_{\mathrm{rec}}\right.$, Table 2$)$. However, mean recession rates over the first six 223 hours of the recession $\left(\mathrm{K}_{\mathrm{r}}\right.$, Table 2$)$ were steeper than that of the stream for five pipes.

Peak and total storm discharge both correlated strongly and positively with most storm event precipitation variables (Table 3). Total precipitation and precipitation intensity were strongly correlated with peak flows, whilst rainfall duration was the most important factor controlling the volume of water flowing through the pipes during storms. There is little correlation between storm event pipe flow characteristics and water-table depth. This lack of correlation appears to be because 230 stream and pipe discharge are dominated by periods when the water table is within $5 \mathrm{~cm}$ of the 231 surface (e.g. Figure 4). When examining the mean characteristics of the eight pipes and the stream 232 there were no significant associations between maximum DCA and mean lag times, hydrograph 233 intensity or hydrograph recession metrics. 
235 Between each month of the 18-month study the flow summed across all the gauged pipes contributed 1.3 to $3.9 \%$ of streamflow although there were no clear seasonal trends. Over the 12 months from 24 April 2008, when upscaled across the catchment, the total pipe flow was estimated to account for $13.7 \%$ of stream flow. Perennial pipes were found to account for an estimated 12.2 $\%$ of flow at the catchment outlet compared to $1.5 \%$ for ephemeral pipes. The proportion of flow at the catchment outlet due to pipe flow varied over time and throughout rainfall events (Figure 5).

241 During periods of low streamflow the proportion of discharge at the catchment outlet contributed by the monitored pipes was greater than during rainfall events. For the periods when streamflow was less than $0.4 \mathrm{~L} \mathrm{~s}^{-1}$ (i.e. lowest $10 \%$ of flows), flows from the gauged pipes were estimated to contribute $20 \%$ to streamflow. When upscaled to all detected pipes, pipe discharge was actually greater than the total stream runoff. Only at P8 was there an increase in the proportion of stream runoff delivered by the pipe outlet during rainfall events; this pipe only flowed during large storm flow events. Figure 5 also reveals spikes in the proportion of flow provided by some of the pipes at the beginning of rainfall events indicating that these pipes respond more quickly to rainfall than the stream.

The flow exceedance curves are shown in Figure 6. Over 58\% of the total stream discharge from the site occurred during only $10 \%$ of the time. In comparison only $0.34 \%$ of total discharge from the site occurred during the $10 \%$ of time that the flow was at its lowest. The different behaviour of flows from P8 compared to the other pipes is evident from the plot. Pipe P8 produced over $89 \%$ of its discharge during $10 \%$ of the time. The other three ephemerally-flowing pipes had flow exceedance curves with a similar shape to each other and also similar to the stream. The three perennially-flowing pipes have similar flow exceedance curves to each other. Pipes P3 and P7 produced over 72 and $76 \%$ respectively of their discharge during only $10 \%$ of the time. P6 had a 
sustained baseflow during the study and had the least steep flow exceedance curve at the site, and produced only $43 \%$ of its discharge during the wettest $10 \%$ of the time.

\section{Discussion and conclusions}

263 Pipeflow was an important component of stream hydrology in Cottage Hill Sike with flow from the 264 gauged pipe outlets alone accounting for around $2.2 \%$ of streamflow during the study period. If these gauged pipe outlets were a representative sample of the pipes within the catchment, we estimate that $13.7 \%$ of streamflow was produced from the pipe system. Perennially-flowing pipes were of greater hydrological importance to annual streamflow compared to ephemeral pipes. While other pipes within the catchment could behave differently from the monitored pipes, there did appear to be consistency in hydrological behaviour within perennial pipe types and within ephemeral pipe types, with the exception of P8 (see below). Furthermore, there are likely to be pipes within the catchment that are undetected meaning our value of $13.7 \%$ will be an underestimate of the total pipeflow contributions to stream flow.

The substantial contribution of pipeflow to streamflow in Cottage Hill Sike is a very important

275 finding. Earlier work on pipeflow in blanket peat had suggested that it could be important (e.g. accounting for $10 \%$ of streamflow in Little Dodgen Pot Sike; Holden and Burt, 2002) and so the results from Cottage Hill Sike provide strong evidence that this proportion of pipeflow contributions is typical, at least locally (Little Dodgen Pot Sike is $3 \mathrm{~km}$ from Cottage Hill Sike). It should also be noted that our present study was much more comprehensive than that undertaken by 280 Holden and Burt (2002) (e.g. 100 storms analysed versus 14 in the earlier paper; 18 months of 281 continuous data compared to 5). Jones and Crane (1984) reported that $49 \%$ of streamflow was produced by soil pipes in histic podzols (i.e. not deep peat) at a site in Wales and so our results for the role of pipeflow are not unusual in that context. However, our results are clearly important 
284 because they have implications in terms of the wider understanding of how blanket peatlands 285 function hydrologically.

There was a large range (320-fold) in maximum discharge recorded from individual pipes. The overall maximum flow recorded from any of the pipes was similar to those reported elsewhere. Values include $8.5 \mathrm{~L} \mathrm{~s}^{-1}$ from an ephemeral pipe in Casper Creek, California (Zeimer and Albreight, 1987), and 1.1 L s${ }^{-1}$ in a sandy till in Quebec (Roberge and Plamondon, 1987). In peatlands, peak flow rates from individual pipes have been reported of $0.7 \mathrm{~L} \mathrm{~s}^{-1}$ from the James Bay Lowlands (Woo and DiCenzo, 1988), 1.0 L s ${ }^{-1}$ from a peaty podzol in southwest England (Weyman, 1970), 2.0 $\mathrm{L} \mathrm{s}^{-1}$ from a shallow peat in Wales (Gilman and Newson, 1980), and 4.6 $\mathrm{L} \mathrm{s}^{-1}$ in deep blanket peat (Holden and Burt, 2002). Over an 18 month period, Chapman (1994) recorded flow from an ephemeral pipe outlet in a shallow peat in mid-Wales during 66 storms and maximum flows ranged between 0.9 and $9.88 \mathrm{~L} \mathrm{~s}^{-1}: 78 \%$ of storms had a maximum pipe flow rate of $<4 \mathrm{~L} \mathrm{~s}^{-1}$ and rates $>6$ $\mathrm{L} \mathrm{s}^{-1}$ were rare and associated with very intense rain that generally occurred in the summer. The large range in total storm discharge between the Cottage Hill Sike pipes (Table 1) was similar to that observed in the Maesnant catchment (mid-Wales) by Jones (2004).

The ephemeral hydrological behaviour of P8 was somewhat different from that of the other three ephemeral pipes monitored in terms of storm response and flow exceedance curves. P8 behaved like an 'overflow pipe' which switched on and off rapidly and was only activated during the highest

304 flows. Nevertheless when flow did occur rates were high. We did not include P8 in our calculations to determine the wider role of ephemeral pipes within the catchment and classified this as a separate 'overland flow' pipe type. If there were other such overflow pipes within the catchment then we may have underestimated the role of ephemeral pipes in streamflow and the overall role of pipes in streamflow within the catchment. 
310 All gauged pipes responded rapidly to rainfall events and had a flashy flow regime, including those

311 whose outlets were more than a metre below the peat surface. It is known that pipe networks 312 undulate throughout a peat profile along their course, so it may be that pipes are close to the surface 313 in some places and very deep (>> 1m) in others (Holden, 2004). The rapid response of pipes to 314 rainfall and the dominance of stormflow in peatland pipe systems, suggests that surface and near315 surface runoff rapidly entered the pipe networks. This is likely to have a major influence on the 316 chemistry and solute load of the water exported from the pipes. However, the lag times were longer 317 for the blanket peat pipes studied in Cottage Hill Sike than those reported in histic podzols at 318 Plynlimon, where ephemeral pipe flow responded within 20 to 30 minutes of rainfall starting 319 (Muscutt, 1991).

321 The majority of discharge generated in both pipes and the stream occurred when the water table at 322 the ECN monitoring site was within $5 \mathrm{~cm}$ of the peat surface. Peak flow from the pipes usually 323 coincided with times when the water table was at the peatland surface. However, care must be taken 324 when drawing conclusions from these results because water table levels were measured at just one 325 location in the catchment, and water tables in the vicinity of pipes may have differed from those at 326 the single location. Further research is needed to elucidate water-table effects on pipeflow in 327 peatland catchments because many ephemeral pipes show little or no flow for long periods even 328 though the water table appears to be well above the pipe outlets. Parts of pipe networks could act as 329 air-filled voids below the water table within peatlands for part of the time. Such air-filled voids may 330 be important for biogeochemical cycling in peatlands.

332 Despite the flashy response of pipe outlets to rainfall, the gauged pipes tended to have more 333 subdued hydrograph recessions (although not over the first 6 hours of the recession) than the stream 
at the catchment outlet. Indeed the hydrograph intensity index for five of the pipes was less than that of the stream. Given that individual pipe catchments should be very small in comparison to the stream catchment area and therefore have more flashy hydrographs (and hence a larger hydrograph intensity), this shows an important distinction between pipeflow and streamflow regimes. These results are probably indicative of the dominant role of saturation-excess overland flow during storm events in blanket peat systems and the relatively slower route for water through pipe networks when compared to overland flow. Overland flow is known to account for $81.5 \%$ of runoff from the peat

341 at Moor House (not including pipes) while $17.7 \%$ of the flow is produced by the upper $5 \mathrm{~cm}$ of the 342 peat (Holden and Burt, 2003c). However, while there have been comprehensive studies of water 343 flow travel times in peatland overland flow (e.g. Holden et al., 2008) the studies that examine deep 344 peat pipeflow travel times are less comprehensive (e.g. Holden, 2004) and the latter requires further 345 research.

The proportion of pipeflow contributing to streamflow at any given time was greatest at low stream flows. Jones (1990), working in the Maesnant catchment in Wales, also observed that the contribution of pipe water to streamflow decreased when the catchment was very wet even though the absolute quantity of pipeflow continued to increase. Our measurements suggest that pipeflows are largely responsible for maintaining inter-storm flows at Cottage Hill Sike. Without pipes, the streamflow in blanket peat catchments may be even flashier than for a blanket peat system with pipes. However, the errors in low flow gauging with v-notch weirs may be large when compared to the recorded discharge. When flow in the stream is only $400 \mathrm{~mL} \mathrm{~s}^{-1}$, flow from most individual 355 pipes tends to be $<2 \mathrm{~mL} \mathrm{~s}^{-1}$ which is probably smaller than the reliable measurement range for the v-notch weirs. Hence, the exact low flow values and percent contributions to flow that are reported here should be treated with caution and taken only as indicators of the relative importance of pipeflow during low flow periods. Furthermore, during low-flow periods it was often observed that 
pipeflow would be occurring, albeit very slowly, and yet there was no flow in the headwaters of the stream. This observation suggests that during low flows pipes may emit discharge which then

361 infiltrates into the peat near the pipe outlet rather than going directly into the stream.

362 Notwithstanding these issues, the indications are that pipeflow is important for maintaining stream

363 flow during low-flow periods in blanket peatland and could, therefore, strongly influence

364 streamwater chemistry, water temperature and carbon fluxes. Further work is required to investigate 365 pipeflow chemistry and carbon fluxes and their influence on stream chemistry and carbon fluxes.

366 Given the potentially large role for pipes in streamwater chemistry it will be important to determine 367 the mechanisms and routes by which water enters pipes during low flow, especially because our 368 knowledge of blanket peat saturated hydraulic conductivity suggests that values will be low in all 369 but the near-surface layers. It may be that oxidisation around pipe walls increases local saturated hydraulic conductivity and encourages lateral inflow. However, if this were the case then we will need to determine why there are differences in the processes operating around perennially- and ephemerally-flowing pipes. When all of the pipes across the catchment were examined, the ephemerally-flowing pipe outlets were significantly deeper in the peat than perennially-flowing pipe outlets (Holden et al., in review) and so it may be that perennial flow is largely maintained by drainage of more near-surface peat around pipes rather than deep lateral inflow.

It has been shown that land management (e.g. drainage, more Calluna cover, bare peat) can lead to enhanced pipe development in blanket peatland systems (Holden, 2005a; Holden, 2005b). It is unlikely that changes to streamflow during storms would be evident under increased piping.

380 However, given our findings it would be expected that increased piping would alter the streamflow regime providing larger baseflows and greater loss of peatland water between storm events. Enhanced piping may also have a large impact on streamwater chemistry and carbon fluxes. 


\section{Acknowledgements}

386 The research was funded by UK Natural Environment Research Council (NERC) grant

387 NE/E003168/1 awarded to JH, MFB, AJB and PJC. Cottage Hill Sike is a NERC Centre for 388 Ecology and Hydrology Carbon Catchment and is part of the Moor House Environmental Change

389 Network site. We are grateful to ECN for background data from the catchment and to Natural

390 England for granting access. We gratefully acknowledge the technical assistance of David Ashley 391 and Kirsty Dyson. 


\section{References}

Adamson JK, Scott WA, Rowland AP. 1998. The dynamics of dissolved nitrogen in a blanket peat dominated catchment. Environmental Pollution 99: 69-77.

Baillie IC. 1975. Piping as an erosion process in the uplands of Sarawak. Journal of Tropical Geography 41: 9-15.

Baird AJ. 1997. Field estimation of macropore functioning and surface hydraulic conductivity in a fen peat. Hydrological Processes 11: 287-295.

Billett MF, Charman DJ, Clark JM, Evans CD, Evans MG, Ostle NJ, Worrall F, Burden A, Dinsmore KJ, Jones T, McNamara NP, Parry L, Rowson JG, Rose R. 2010. Carbon balance of UK peatlands: current state of knowledge and future research challenges. Climate Research 45: 13-29, doi: 10.3354/cr00903.

Bryan RB, Jones JAA. 1997. The significance of soil piping processes: inventory and prospect. Geomorphology 20: 209-218.

Carey SK, Woo MK. 2000. The role of soil pipes as a slope runoff mechanism, Subarctic Yukon, Canada. Journal of Hydrology 233: 206-222.

Chapman PJ. 1994. Hydrogeochemical processes influencing episodic stream water chemistry in a headwater catchment, Plynlimon, mid-Wales. Imperial College, University of London: London.

Chappell NA, Sherlock MD. 2005. Contrasting flow pathways within tropical forest slopes of Ultisol soils. Earth Surface Processes and Landforms 30: 735-753.

Clark JM, Lane SN, Chapman PJ, Adamson JK. 2007. Export of dissolved organic carbon from an upland peatland during storm events: implications for flux estimates. Journal of Hydrology 347: 438-447.

Crouch RJ, McGarity JW, Storrier RR. 1986. Tunnel Formation Processes in the Riverina Area of N.S.W., Australia. Earth Surface Processes and Landforms 11: 157-168.

Dinsmore KJ, Smart RP, Billett MF, Holden J, Baird AJ, Chapman PJ. in review. Greenhouse gas losses from peatland pipes: a major pathway for loss to the atmosphere? Journal of Geophysical Research - Biogeosciences.

Evans MG, Burt TP, Holden J, Adamson JK. 1999. Runoff generation and water table fluctuations in blanket peat: evidence from UK data spanning the dry summer of 1995. Journal of Hydrology 221: 141-160.

Gilman K, Newson MD. 1980. Soil pipes and pipeflow; a hydrological study in upland Wales. Geo Books: Norwich.

Glaser PH. 1998. The distribution and origin of mire pools In Patterned Mires and Mire Pools : origin and Development; flora and fauna, Standen V, Tallis JH, Meade R eds). University of Durham: Durham;4-25.

Gunn J. 2000. Introduction. In The Geomorphology of Cuilcagh Mountain, Ireland: A Field Guide for the British Geomorpholical Research Group Spring Field Meeting, May 2000, Gunn J (ed). Limestone Research Group, University of Huddersfield; 1-3.

Gutierrez M, Sancho C, Benito G, Sirvent J, Desir G. 1997. Quantitative study of piping processes in badland areas of Ebro basin, NE Spain. Geomorphology 20: 121-134.

Holden J. 2004. Hydrological connectivity of soil pipes determined by ground-penetrating radar tracer detection. Earth Surface Processes and Landforms 29: 437-442.

Holden J. 2005a. Controls of soil pipe frequency in upland blanket peat. Journal of Geophysical Research 110: F01002, doi:01010.01029/02004JF000143.

Holden J. 2005b. Piping and woody plants in peatlands: cause or effect? . Water Resources Research 41: W06009, doi:06010.01029/02004WR003909.

Holden J. 2009. Flow through macropores of different size classes in blanket peat. Journal of Hydrology 364: 342-348. 
Holden J, Burt TP. 2002. Piping and pipeflow in a deep peat catchment. Catena 48: 163-199.

Holden J, Burt TP. 2003a. Hydraulic conductivity in upland blanket peat: measurement and variability. Hydrological Processes 17: 1227-1237.

Holden J, Burt TP. 2003b. Hydrological studies on blanket peat: the significance of the acrotelmcatotelm model. Journal of Ecology 91: 86-102.

Holden J, Burt TP. 2003c. Runoff production in blanket peat covered catchments. Water Resources Research 39: 1191, doi:1110.1029/2003WR002067.

Holden J, Burt TP, Vilas M. 2002. Application of ground-penetrating radar to the identification of subsurface piping in blanket peat. Earth Surface Processes and Landforms 27: 235-249.

Holden J, Chapman PJ, Labadz JC. 2004. Artificial drainage of peatlands: hydrological and hydrochemical process and wetland restoration. Progress in Physical Geography 28: 95123.

Holden J, Gell KF. 2009. Morphological characterization of solute flow in a brown earth grassland soil with cranefly larvae burrows (leatherjackets). Geoderma 152: 181-186.

Holden J, Kirkby MJ, Lane SN, Milledge DG, Brookes CJ, Holden V, McDonald AT. 2008. Factors affecting overland flow velocity in peatlands. Water Resources Research 44: W06415, doi: 06410.01029/02007WR006052.

Holden J, Rose R. 2011. Temperature and surface lapse rate change: a study of the UK's longest upland instrumental record. International Journal of Climatology 31 doi: 10.1002/joc.2136.

Holden J, Smart RP, Dinsmore K, A.J. B, M.F. B, Chapman PJ. in review. Morphological change of natural pipe outlets in blanket peat. Earth Surface Processes and Landforms.

Jones JAA. 1981. The nature of soil piping: a review of research. Geo Books: Norwich.

Jones JAA. 1990. Piping effects in humid lands. In Groundwater geomorphology; the role of subsurface water in Earth-surface processes and landforms, Higgins CG, Coates DR (eds). Geological Society of America; 111-137.

Jones JAA. 1994. Subsurface flow and subsurface erosion. In Process and form in geomorphology, Stoddart DR (ed). Routledge: London; 74-120.

Jones JAA. 1997. Pipeflow contributing areas and runoff response. Hydrological Processes 11: 3541.

Jones JAA. 2004. Implications of natural soil piping for basin management in upland Britain. Land Degradation \& Development 15: 325-349.

Jones JAA, Crane FG. 1984. Pipeflow and pipe erosion in the Maesnant experimental catchment. In Catchment experiments in fluvial geomorphology, Burt TP, Walling DE (eds). Geo Books: Norwich; 55-72.

Jones JAA, Richardson JM, Jacob HJ. 1997. Factors controlling the distribution of piping in Britain: a reconnaissance. Geomorphology 20: 289-306.

Manley G. 1936. The climate of the northern Pennines: the coldest part of England. Quarterly Journal of the Royal Meteorological Society 62: 103-115.

Manley G. 1942. Meteorological observations on Dun Fell, a mountain station in northern England. Quarterly Journal of the Royal Meteorological Society 68: 151-165.

Markov VD, Khoroshev PI. 1988. Contemporary estimation of the USSR peat reserves. In Proceedings of the 8th International Peat Congress. International Peat Society: Lenningrad.

McCaig M. 1983. Contributions to Storm Quickflow in a Small Headwater Catchment - the Role of Natural Pipes and Soil Macropores. Earth Surface Processes and Landforms 8: 239-252.

Miller JD, Adamson JK, Hirst D. 2001. Trends in stream water quality in Environmental Change Network upland catchments: the first 5 years. The Science of the Total Environment 265: $27-$ 38.

Morris PJ, Waddington JM, Bescoter BW, Turetsky MR. 2011. Conceptual frameworks in peatland ecohydrology: looking beyond the two-layered (acrotelm-catotelm) model. Ecohydrology 4: $1-11,10.1002 /$ eco.1191. 
Muscutt AD. 1991. Flow generation and stormflow hydrochemistry in a small upland catchment in Mid-Wales. Ph.D. Thesis, University of London, London.

Norrstrom AC, Jacks G. 1996. Water pathways and chemistry at the groundwater surface water interface to Lake Skjervatjern, Norway. Water Resources Research 32: 2221-2229.

Price JS. 1992. Blanket Bog in Newfoundland 2. Hydrological Processes. Journal of Hydrology 135: 103-119.

Rapson GL, Sykes MT, Lee WG, Hewitt AE, Agnew ADQ, Wilson JB. 2006. Subalpine gully-head ribbon fens of the Lammerlaw and Lammermoor Ranges, Otago, New Zealand. New Zealand Journal of Botany 44: 351-375.

Roberge J, Plamondon AP. 1987. Snowmelt Runoff Pathways in a Boreal Forest Hillslope, the Role of Pipe Throughflow. Journal of Hydrology 95: 39-54.

Rosa E, Larocque M. 2008. Investigating peat hydrological properties using field and laboratory methods: application to the Lanoraie peatland complex (southern Quebec, Canada). Hydrological Processes 22: 1866-1875.

Sayer AM, Walsh RPD, Bidin K. 2006. Pipeflow suspended sediment dynamics and their contribution to stream sediment budgets in small rainforest catchments, Sabah, Malaysia. Forest Ecology and Management 224: 119-130.

Sykes JM, Lane AMJ. 1996. The United Kingdom Environmental Change Network: protocols for standard measurements of terrestrial sites. Natural Environment Research Council: London; 220.

Terajima T, Sakamoto T, Shirai T. 2000. Morphology, structure and flow phases in soil pipes developing in forested hillslopes underlain by a Quaternary sand-gravel formation, Hokkaido, northern main island in Japan. Hydrological Processes 14: 713-726.

Thorp M, Glanville P. 2003. Mid-Holocene sub-blanket peat alluvia and sediment sources in the upper Liffet Valley, Co. Wicklow, Ireland. Earth Surface Processes and Landforms 28: 1013-1024.

Tipping E, Billett MF, Bryant CL, Buckingham S, Thacker SA. 2010. Sources and ages of dissolved organic matter in peatland streams: evidence from chemistry mixture modelling and radiocarbon data. Biogeochemistry 100: 121-137, DOI 110.1007/s10533-10010-1940910536.

Uchida T, Kosugi K, Mizuyama T. 1999. Runoff characteristics of pipeflow and effects of pipeflow on rainfall-runoff phenomena in a mountainous watershed. Journal of Hydrology 222: 1836.

Uchida T, Tromp-van Meerveld I, McDonnell JJ. 2005. The role of lateral pipe flow in hillslope runoff response: an intercomparison of non-linear hillslope response. Journal of Hydrology 311: 117-133.

Verachtert E, Van Den Eeckhaut M, Poesen J, Deckers J. 2010. Factors controlling the spatial distribution of soil piping erosion on loess-derived soils: A case study from central Belgium. Geomorphology 118: 339-348.

Weyman DR. 1970. Surface and subsurface runoff in a small basin. PhD thesis, University of Bristol: Bristol.

Woo M-K, DiCenzo P. 1988. Pipe flow in James Bay coastal wetlands. Canadian Journal fo Earth Sciences 25: 625-629.

Zeimer RR, Albreight JS. 1987. Subsurface pipeflow dynamics of north-coastal Califrornia swale systems. IAHS publication 165: 71-80.

Zhu TX. 1997. Deep-seated, complex tunnel systems - a hydrological study in a semi-arid catchment, Loess plateau, China. Geomorphology 20: 255-267.

Zhu TX. 2003. Tunnel development over a 12 year period in a semi-arid catchment of the Loess Plateau, China. Earth Surface Processes and Landforms 28: 507-525. 
542

543

544 
Table 1. Pipe and stream flow characteristics for 12 months from 24 April 2008.

\begin{tabular}{|c|c|c|c|c|c|c|c|c|c|c|c|}
\hline \multirow[b]{2}{*}{ Site } & \multicolumn{5}{|c|}{ General characteristics } & \multicolumn{6}{|c|}{ Storm analysis } \\
\hline & $\begin{array}{l}\text { Pipe } \\
\text { flow } \\
\text { type }\end{array}$ & $\begin{array}{c}\text { Pipe } \\
\text { entrance } \\
\text { diameter } \\
(\mathrm{cm})\end{array}$ & $\begin{array}{l}\text { Depth of } \\
\text { pipe from } \\
\text { peat } \\
\text { surface } \\
\text { (cm) }\end{array}$ & $\begin{array}{c}\text { Maximum } \\
\text { discharge } \\
\left(\mathrm{L} \mathrm{s}^{-1}\right)\end{array}$ & $\begin{array}{c}\text { Minimum } \\
\text { discharge } \\
\left(\mathrm{L} \mathrm{s}^{-1}\right)\end{array}$ & $\begin{array}{c}\text { Total } \\
\text { number of } \\
\text { storm } \\
\text { events } \\
\text { recorded } \\
\end{array}$ & $\begin{array}{c}\text { Range of } \\
\text { rainfall } \\
\text { events }(\mathbf{m m})\end{array}$ & $\begin{array}{l}\text { Range of } \\
\text { total storm } \\
\text { discharge } \\
\left(\mathrm{m}^{3}\right)\end{array}$ & $\begin{array}{c}\text { Total storm } \\
\text { discharge as } \\
\% \text { of stream } \\
\text { discharge }\end{array}$ & $\begin{array}{c}\text { Estimated } \\
\text { maximum } \\
\text { DCA }\left(\mathbf{m}^{2}\right)(\% \\
\text { of catchment } \\
\text { in brackets })\end{array}$ & $\begin{array}{c}\text { Annual runoff } \\
\text { coefficient } \\
\text { based on } \\
\text { maximum } \\
\text { DCA }\end{array}$ \\
\hline $\mathrm{P} 1$ & $\mathrm{E}$ & 10 & 47 & 0.016 & 0 & 31 & $3.0-85.4$ & $0.03-1.22$ & $0.005-0.055$ & $178(0.10)$ & $0.25^{+}$ \\
\hline $\mathrm{P} 2$ & $\mathrm{E}$ & 3 & 75 & 0.016 & 0 & 55 & $2.8-40.8$ & $0.05-0.93$ & $0.002-0.048$ & $100(0.06)$ & 0.27 \\
\hline P3 & $\mathrm{P}$ & 30 & 25 & 3.850 & $2 \times 10^{-6}$ & 100 & $2.2-85.4$ & $2.60-183.00$ & $0.120-3.770$ & $6151(3.54)$ & 0.22 \\
\hline $\mathrm{P} 4$ & $\mathrm{E}$ & 3 & 60 & 0.012 & 0 & 79 & $2.8-85.4$ & $0.010-1.93$ & $0.001-0.059$ & $82(0.05)$ & 0.23 \\
\hline P5 & $\mathrm{E}$ & 1 & 100 & 0.016 & 0 & 62 & $3.0-40.8$ & $0.02-0.94$ & $0.004-0.046$ & $78(0.04)$ & 0.27 \\
\hline P6 & $\mathrm{P}$ & 15 & 100 & 0.290 & $5 \times 10^{-3}$ & 104 & $2.6-85.4$ & $0.90-32.04$ & $0.043-2.254$ & $2711(1.56)$ & 0.23 \\
\hline P7 & $\mathrm{P}$ & 6 & 30 & 0.370 & $6 \times 10^{-4}$ & 104 & $2.8-85.4$ & $0.47-28.35$ & $0.026-0.389$ & $838(0.48)$ & 0.26 \\
\hline P8 & $\mathrm{E}$ & 10 & 160 & 2.700 & 0 & 109 & $2.2-85.4$ & $0.03-138.86$ & $0.003-2.344$ & 3243 (1.87) & 0.29 \\
\hline Stream & $\mathrm{P}$ & & & 264 & $2 \times 10^{-2}$ & 102 & $2.2-85.4$ & $278-17754$ & & $173600^{*}$ & 0.84 \\
\hline
\end{tabular}

*Total measured catchment area.

${ }^{+}$Mean of 31 storm events as there is insufficient data to provide an annual runoff coefficient. 
Table 2. Mean hydrograph response variables determined from single-peaked storms over the 12 month period from 24 April 2008.

\begin{tabular}{|c|c|c|c|c|c|c|c|}
\hline Site $(n)$ & $\begin{array}{c}\text { Time to } \\
\text { max flow } \\
(\mathrm{hr})\end{array}$ & $\begin{array}{c}\text { Start lag } \\
(\mathrm{hr})\end{array}$ & $\begin{array}{c}\text { Storm } \\
\text { discharge } \\
\left(\mathrm{m}^{3}\right)\end{array}$ & $\begin{array}{c}\text { Peak } \\
\text { lag } \\
(\mathrm{hr})\end{array}$ & $\begin{array}{c}\text { Hydrograph } \\
\text { intensity } \\
\text { index }\left(\mathrm{s}^{-1}\right)\end{array}$ & $\mathrm{Kr}$ & $\mathrm{T}_{\text {rec }}(\mathrm{hr})$ \\
\hline P1 (18) & 6.5 & 2.8 & 0.50 & 5.3 & 30.7 & 0.52 & 22.1 \\
\hline P2 (20) & 4.8 & 2.3 & 0.33 & 2.6 & 24.4 & 0.48 & 30.6 \\
\hline P3 (73) & 6.4 & 2.6 & 16.40 & 4.6 & 24.9 & 0.53 & 26.7 \\
\hline P4 (37) & 6.2 & 2.5 & 0.26 & 4.2 & 24.3 & 0.61 & 23.1 \\
\hline P5 (23) & 7.2 & 2.7 & 0.38 & 5.1 & 19.9 & 0.70 & 30.6 \\
\hline P6 (57) & 4.4 & 2.3 & 4.18 & 2.6 & 23.5 & 0.65 & 24.6 \\
\hline P7 (43) & 3.6 & 2.2 & 2.67 & 1.9 & 39.2 & 0.34 & 24.8 \\
\hline P8 (58) & 3.5 & 4.4 & 14.18 & 3.8 & 50.0 & 0.26 & 8.8 \\
\hline Stream & 5.6 & 3.5 & 1848 & 4.5 & 28.1 & 0.56 & 19.7 \\
$(65)$ & & & & & & & \\
\hline
\end{tabular}

Time to max flow = time from initiation of the storm response in the pipe or stream to peak flow.

Start lag = time to start of flow increase from the initiation of rainfall.

Peak lag = time to maximum flow from peak rainfall.

$\mathrm{Kr}=$ flow $6 \mathrm{hrs}$ after max flow/max flow.

Hydrograph intensity index $=(\max$ flow/total storm discharge $) \times 10^{6}$.

$\mathrm{T}_{\text {rec }}=$ Time from hydrograph peak to return to pre-event discharge.

$n=$ Number of rainfall events used in analysis 
Table 3. Correlation coefficients for flow and precipitation characteristics.

\begin{tabular}{|c|c|c|c|c|c|c|}
\hline Site $(n)$ & $\begin{array}{l}\text { Discharge } \\
\text { factor }\end{array}$ & $\begin{array}{l}\text { Total } \\
\text { rainfall }\end{array}$ & $\begin{array}{l}\text { Rainfall } \\
\text { duration }\end{array}$ & $\begin{array}{l}\text { Storm mean } \\
\text { rainfall } \\
\text { intensity }\end{array}$ & $\begin{array}{l}\text { Storm } \\
\text { maximum } 5 \\
\text { min rainfall }\end{array}$ & $\begin{array}{l}\text { Water-table } \\
\text { depth }\end{array}$ \\
\hline \multirow{2}{*}{ P1 (18) } & Peak & 0.181 & -0.053 & 0.203 & 0.041 & $* 0.483$ \\
\hline & Total & 0.377 & 0.208 & 0.073 & 0.170 & 0.461 \\
\hline \multirow{2}{*}{ P2 (20) } & Peak & $* 0.678$ & 0.324 & $* 0.555$ & $* 0.725$ & $*_{-0.603}$ \\
\hline & Total & $* 0.562$ & 0.434 & 0.289 & 0.435 & $*_{-} 0.782$ \\
\hline \multirow{2}{*}{ P3 (73) } & Peak & $* 0.759$ & $* 0.286$ & $* 0.503$ & $* 0.679$ & 0.124 \\
\hline & Total & $* 0.815$ & $* 0.362$ & $* 0.487$ & $* 0.593$ & 0.197 \\
\hline \multirow{2}{*}{ P4 (37) } & Peak & $* 0.833$ & $* 0.563$ & $* 0.527$ & $* 0.714$ & -0.012 \\
\hline & Total & $* 0.830$ & $* 0.690$ & $* 0.428$ & $* 0.583$ & -0.060 \\
\hline \multirow{2}{*}{ P5 (23) } & Peak & $* 0.824$ & $* 0.520$ & $* 0.576$ & $* 0.786$ & -0.153 \\
\hline & Total & $* 0.801$ & $* 0.802$ & 0.251 & $* 0.419$ & -0.094 \\
\hline \multirow{2}{*}{ P6 (57) } & Peak & $* 0.766$ & 0.084 & $* 0.567$ & $* 0.787$ & -0.180 \\
\hline & Total & $* 0.515$ & $* 0.391$ & 0.220 & $* 0.319$ & -0.071 \\
\hline \multirow{2}{*}{ P7 (43) } & Peak & $* 0.842$ & 0.106 & $* 0.653$ & $* 0.790$ & 0.065 \\
\hline & Total & $* 0.789$ & 0.128 & $* 0.555$ & $* 0.634$ & 0.088 \\
\hline \multirow{2}{*}{ P8 (58) } & Peak & $* 0.884$ & $* 0.368$ & $* 0.618$ & $* 0.779$ & 0.099 \\
\hline & Total & $* 0.878$ & $* 0.515$ & $* 0.484$ & $* 0.663$ & 0.042 \\
\hline \multirow{2}{*}{ Flume (65) } & Peak & $* 0.887$ & $* 0.358$ & $* 0.629$ & $* 0.748$ & $* 0.301$ \\
\hline & Total & $* 0.897$ & $* 0.464$ & $* 0.553$ & $* 0.593$ & $* 0.307$ \\
\hline
\end{tabular}

$*$ correlation coefficient significant at the $p \leq 0.05$ level 


\section{Figure captions}

Figure 1. Map showing the location of Cottage Hill Sike within the Moor House National Nature Reserve, UK, and location of sampled pipes.

Figure 2. Hydrographs and precipitation for the sampled pipes and stream in the Cottage Hill Sike catchment for the period 25 April 2008 to 04 May 2008.

Figure 3. Hydrographs and precipitation for the sampled pipes and stream in the Cottage Hill Sike catchment for an example storm starting on 30 April 2008.

Figure 4. Water-table depth and discharge for $\mathrm{P} 2$ and the stream for the period spring to early summer 2008.

Figure 5. The proportion of discharge in the stream contributed by each of the sampled pipes between 24 April 2008 and 10 May 2008.

Figure 6. Flow exceedance curves for the stream and the pipes in Cottage Hill Sike for the 12 months from 24 April 2008. 


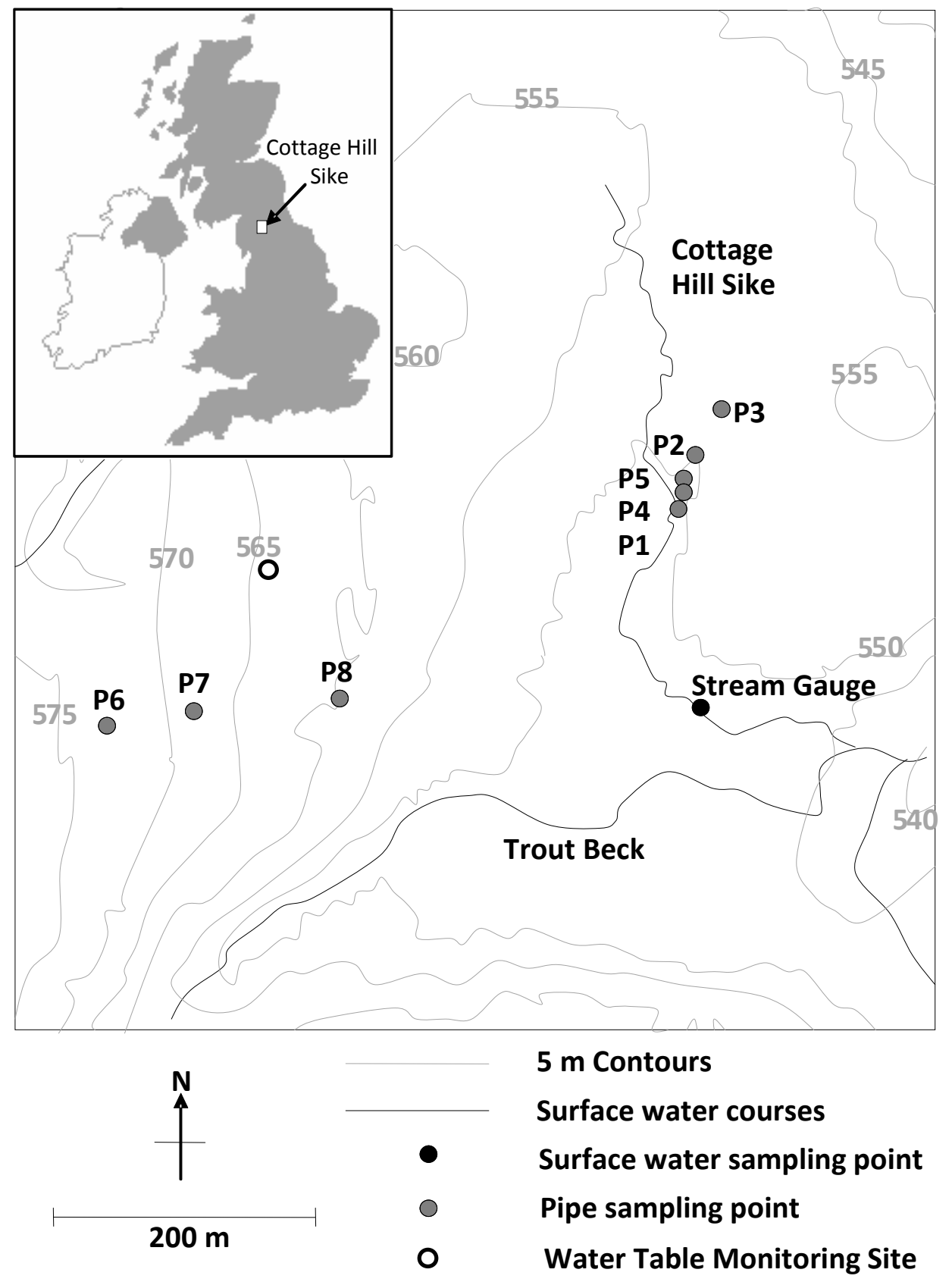

Figure 1. Map showing the location of Cottage Hill Sike within the Moor House National Nature Reserve, UK, and location of sampled pipes. 


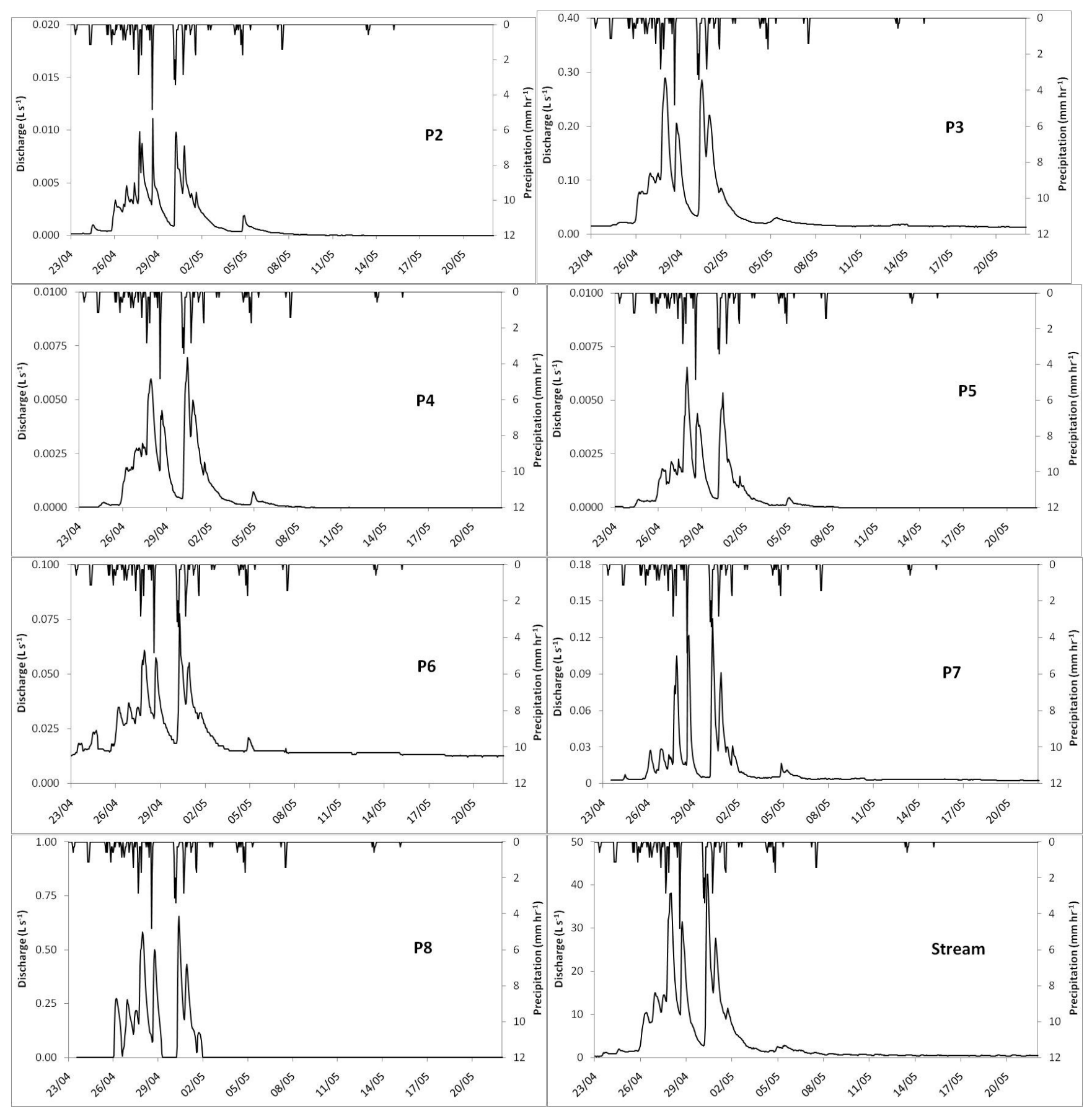

Figure 2. Hydrographs and precipitation for the sampled pipes and stream in the Cottage Hill Sike catchment for the period 25 April 2008 to 04 May 2008. Note the difference in the $y$-axis scales. 


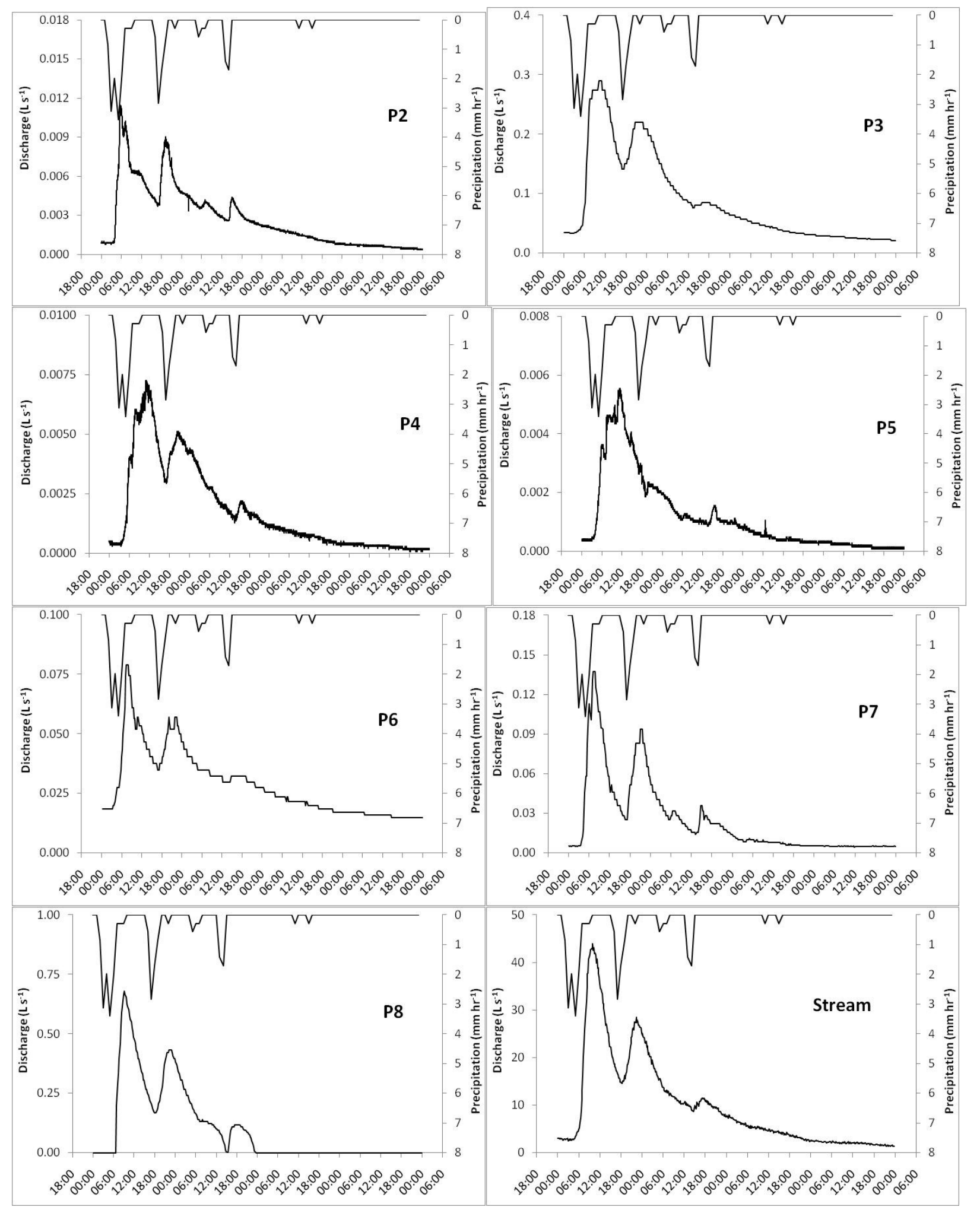

Figure 3. Hydrographs and precipitation for the sampled pipes and stream in the Cottage Hill Sike catchment for an example storm starting on 30 April 2008. Note the difference in the $y$-axis scales. 


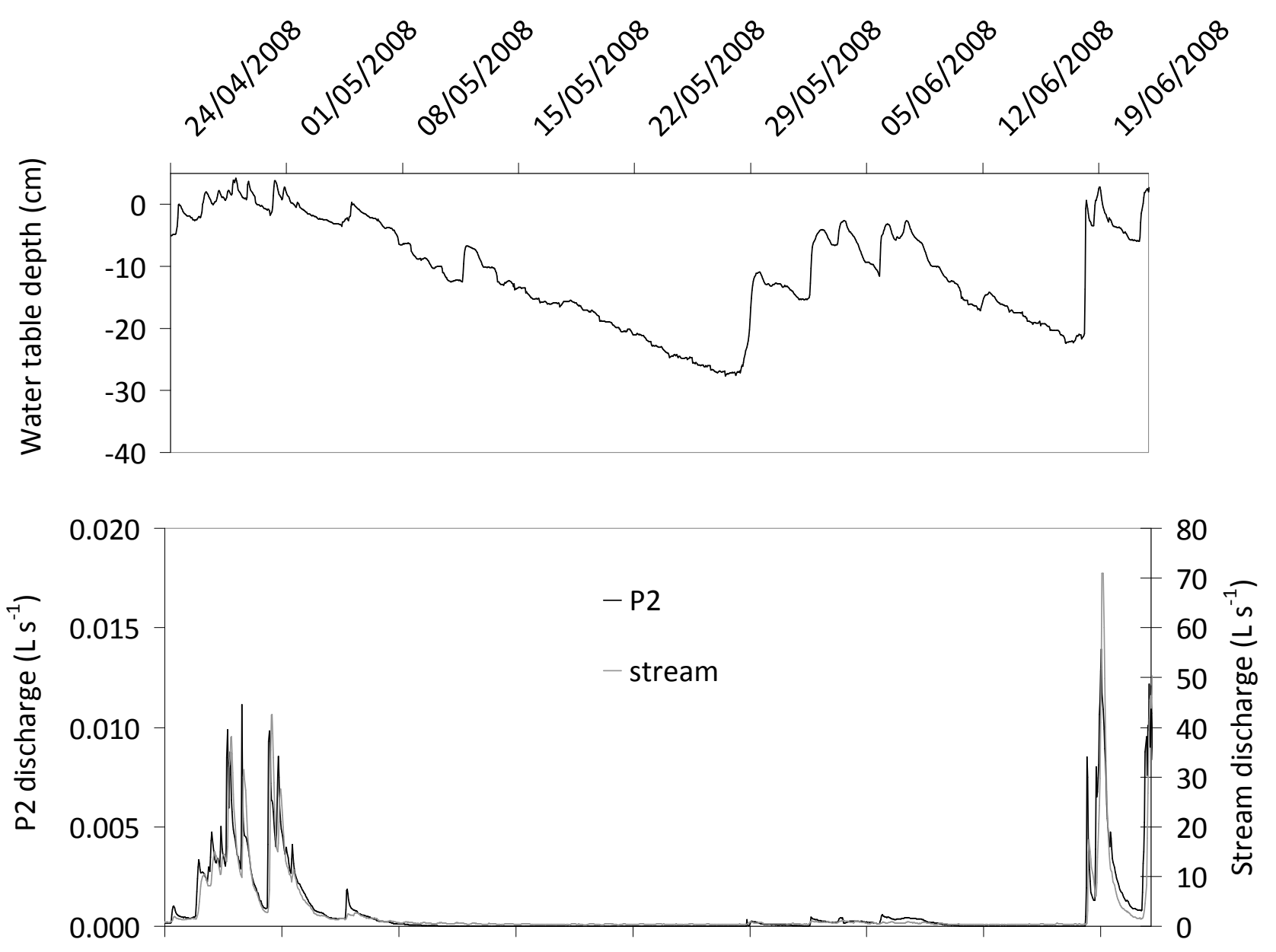

Figure 4. Water-table depth and discharge for P2 and the stream for the period spring to early summer 2008 

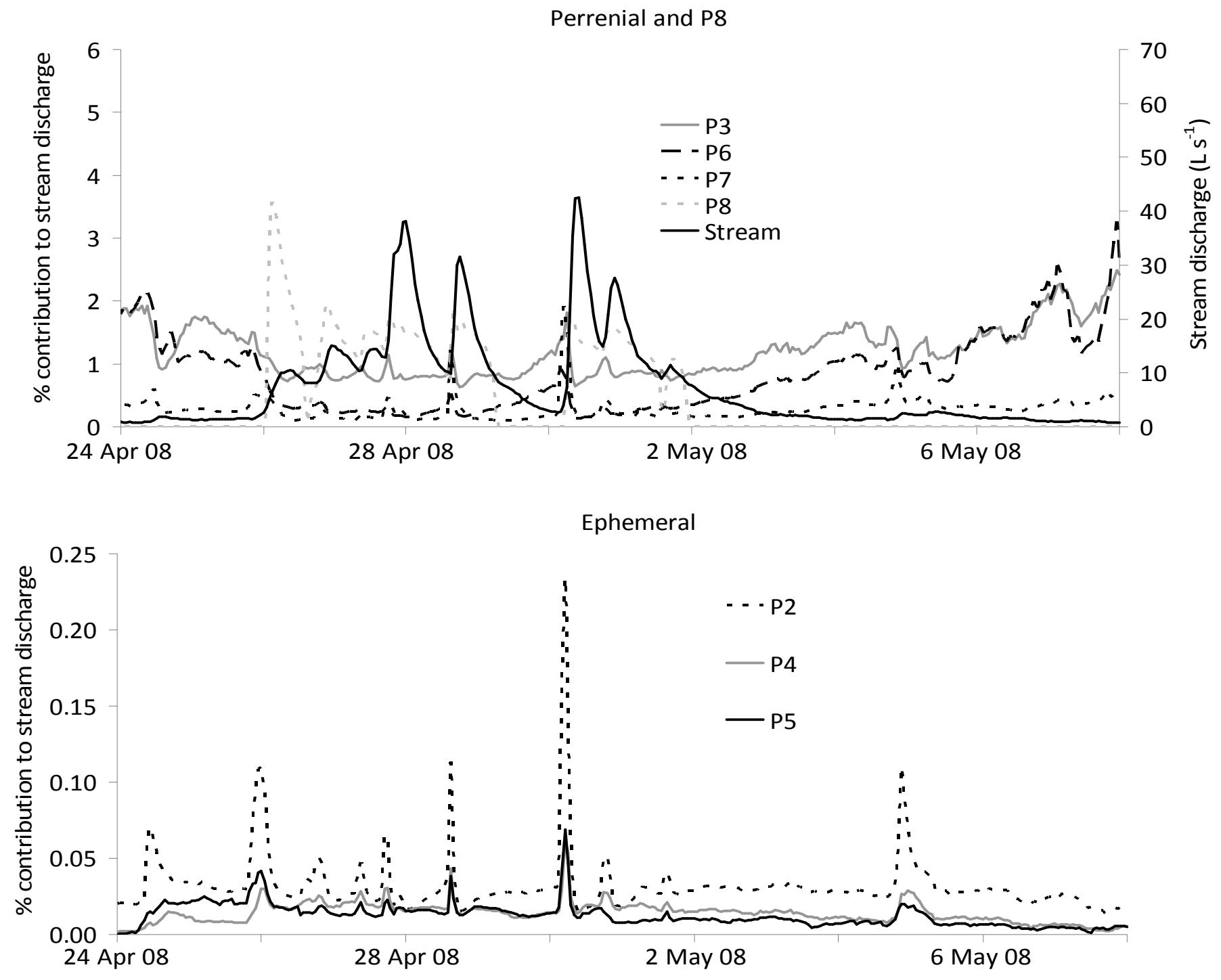

Figure 5. The proportion of discharge in the stream delivered by each of the sampled pipes between 24 April 2008 and 10 May 2008 


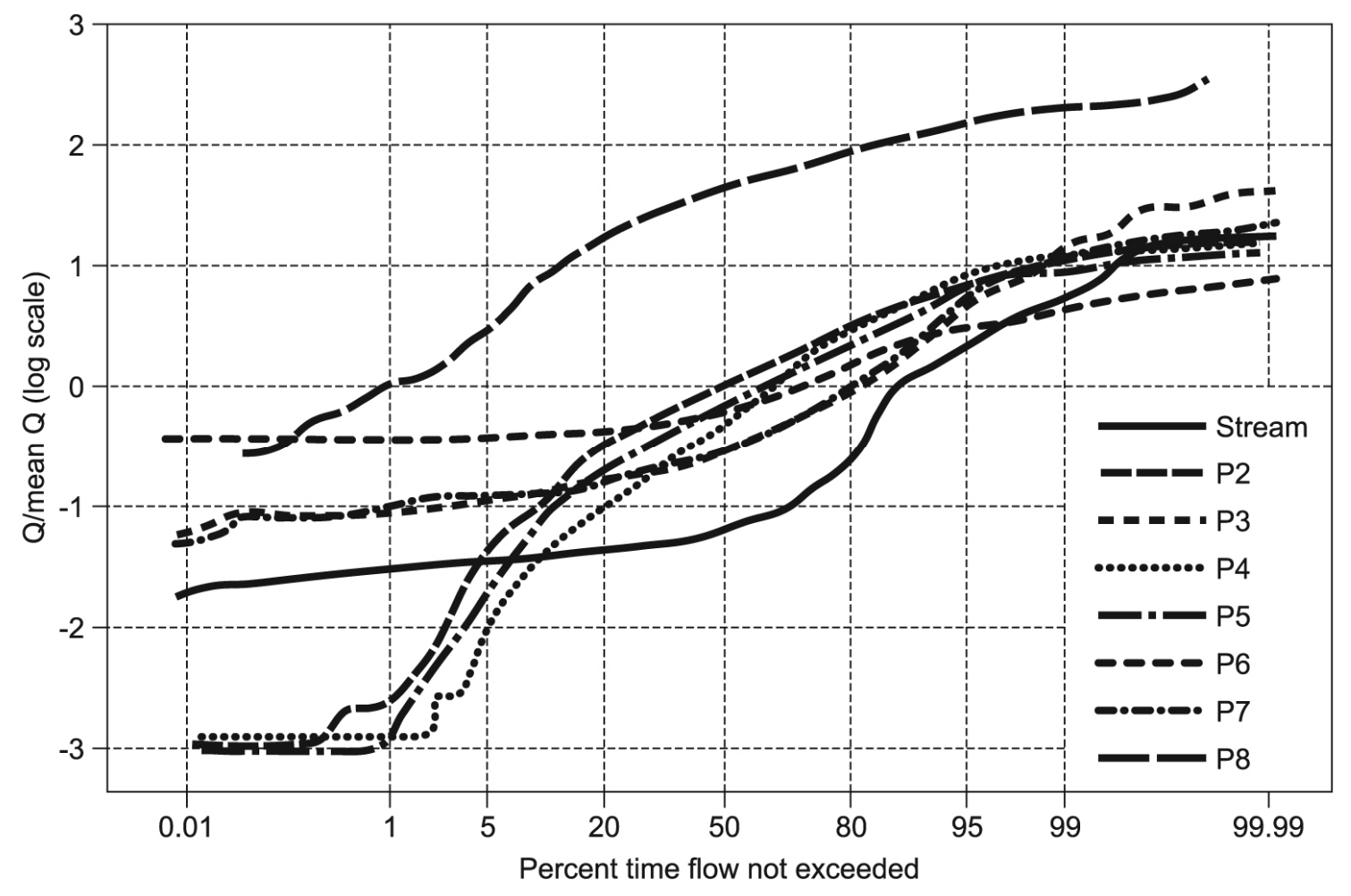

Figure 6. Flow exceedance curves for the stream and the pipes in Cottage Hill Sike for the 12 months from 24 April 2008. 


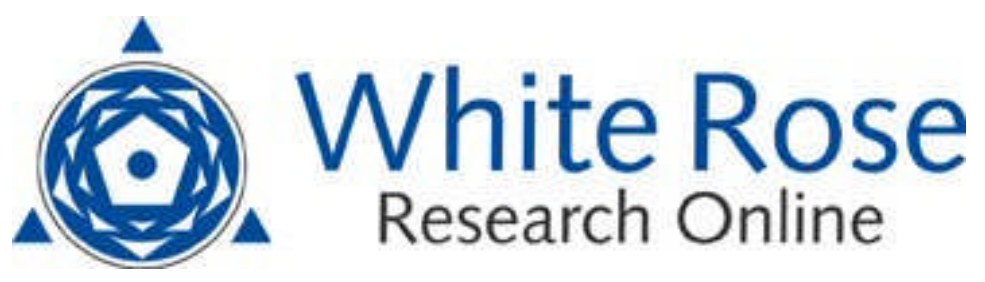

\section{Universities of Leeds, Sheffield and York http://eprints.whiterose.ac.uk/}

This is an author produced version of a paper published in Hydrological Processes

White Rose Research Online URL for this paper:

http://eprints.whiterose.ac.uk/id/eprint/77259

\section{Paper:}

Smart, RP, Holden, J, Baird, AJ, Dinsmore, KJ, Billett, MF, Chapman, PJ and Grayson, R (2013) The dynamics of natural pipe hydrological behaviour in blanket peat. Hydrological Processes, 27 (11). $1523-1534$

http://dx.doi.org/10.1002/hyp.7746 